\title{
Influence of Technology on the Study Habits of Students at RAK Medical and Health Sciences
} University

\author{
Dr. Huma Zaidi ${ }^{* 1}$, Dr. Rabab Abd El Kader ${ }^{2,6}$, Ms. Sheeba David ${ }^{3}$, Dr. Abeer Sharmin Rahman ${ }^{4}$, \\ Dr. Raghavendra Bhat ${ }^{5}$
}

${ }^{1}$ Assistant Professor, Department of General Education, RAK Medical and Health Sciences University, UAE. huma@rakmhsu.ac.ae

${ }^{2}$ Assistant Professor, RAK College of Nursing, RAK Medical and Health Sciences University, UAE. rabab@ rakmhsu.ac.ae

${ }^{3}$ Lecturer, RAK College of Nursing, RAK Medical and Health Sciences University, UAE. sheeba@ rakmhsu.ac.ae

${ }^{4}$ Instructor, RAK College of Medicine, RAK Medical and Health Sciences University, UAE. abeer.rahman@ rakmhsu.ac.ae

${ }^{5}$ Professor \& Chairperson, Department of Internal Medicine, RAK College of Medicine, RAK Medical and Health Sciences University, UAE. raghavendra@ rakmhsu.ac.ae

${ }^{6}$ Lecturer, College of Nursing, Mansoura University, Egypt. rabab@ rakmhsu.ac.ae

Corresponding Author: Dr. Huma Zaidi; huma@ rakmhsu.ac.ae

Received 03 November 2019;

Accepted 15 November 2019;

Published 24 November 2019

\begin{abstract}
This study examined how technology influences the study habits of students at RAK Medical and Health Sciences University. A cross sectional survey was conducted among 306 health sciences students using a self-administered questionnaire about their study habits (preparation for exam, place of study, use of text books / online study, device used, time spent on technology) and use of technology. The results showed that students rely more on technology than text books to study. Further studies can be conducted to investigate how technology can be used to improve their psychomotor and linguistic skills including communication skills which are vital for health care professionals.
\end{abstract}

Keywords: Study habits, technology, university students, influence

\section{Introduction}

A 'habit' is a set routine that is difficult to give up. 'Study habit' means the regular schedule that a student follows to accomplish his academic tasks like attending lectures, preparing notes, studying out of class, revising, and completing his assignments etc. In the 21 st Century, internet technology has revolutionized the way students work, communicate, study and perform the other tasks of their lives. The influence of technology has become noticeable as it provides such instant access to the information that retains the interest of the students and becomes a challenge for the teacher. Students bring their laptops and mobiles to the classrooms, where free Wi-Fi is available, which is not always appreciated. As the speed of internet increases, so does the number of tools that utilize this still growing technology (Colley \& Maltby, 2008).

With the advent of electronic mail (e-mail), e-books, research databases etc., internet has become a primary medium for students' day-to-day activities. Azikiwe (as cited in Igun \& Adogbeji, 2007) defined study habits as the way and manner a student plans his or her private reading outside lecture hours in order to master a particular subject or topic. Study habits help students master their areas of specialization. Al Hilawani and Sartawi (1997) defined study skills as the "skills and habits necessary for getting to know and retrieving information". However, there cannot be any one schedule that is considered as the best one because students have their own learning habits depending on their convenience and circumstances, but it is directly proportional to his results. If a student is able to score well in his exams, his study habits are generally accepted as good and vice versa. Hence study habits can be defined as the way in which a student organizes his time to achieve his desired grades.

In the age of technology, mobiles, laptops and tablets can be used efficiently and effectively for collecting information from the internet. These gadgets also help the students to record the lecture and study at a more convenient time. Studies have shown that people learn considerably better from a combination of both words and images (which technology enables) than merely from words alone (Mayer, 2005).

Research has indicated a need to change and revise curriculum within health colleges to cope with this revolution in technology (Yamani, 2006), because technology is becoming a highly important source of maintaining currency and gaining 
knowledge within the health profession (Rosenberg, 2001). International ICT Literacy Panel (IILP). (2002) stated that increased implementation of technology will increase students' comprehension of content and development of skills in such areas as analytical reasoning, problem solving, information evaluation and creative thinking. Also, it facilitates the ease with which content can be updated, instructions can be personalized, information can be accessed and distributed and content can be standardized according to (Cradler, 2002) and (Rosenberg, 2001). Using technology would support the active learning of students in an educational environment designed to help students achieve meaningful learning- which in turn, could result in positive, cumulatively progressive gains in learning outcomes (Michael, 2001).

The authors of this research were curious to find out the study habits of the present generation of health care students who have the advantage of technology to avail the e-resources and how they organize their time.

\section{Materials and Methods}

Conducted among 306 students enrolled in College of Medicine, College of Dentistry, College of Pharmacy and College of Nursing, this study aimed to ascertain the extent of influence that technology has over the respondents' study habits

The independent variables were the respondents' gender, nationality, College of studying, medium of instruction in school and year of study in college. As to gender they were classified into male and female, as to nationality, they were classified into Arabs and Non-Arabs, according to colleges, they were divided into College of Medicine, College of Dentistry, College of Pharmacy and College of Nursing. There were two mediums of instructionEnglish and Arabic. Lastly, they were categorized according to their year of study.

Study Duration - 6-9 months

Study Design - Cross-sectional Survey

Study Location - RAK Medical and Health Sciences University, Ras al Khaimah.

Study population - Students (males and females), studying medicine, dentistry, pharmacy and nursing courses at RAKMHSU.

Sample Size Calculation - The sample was estimated at a target population of 1225 . We assumed a confidence interval of 5\% and confidence level of $99 \%$. The first name was selected by Blind Method and then every third name from the list was selected. The sample size needed was 306 .

Subjects and Selection Method - After getting the approval from the Research and Ethical Committee of the university, the students were briefed about the study procedure and their consent was taken.

Inclusion: All the students whose names were selected.

Exclusion: The students who were not willing to participate and whose names were not selected.

\section{Procedure and Methodology}

The researchers conducted a students' survey to understand the influence of technology on their study habits. A structured questionnaire was prepared, validated and distributed to the students of the four colleges in the presence of the faculty. The data was collected and analyzed with SPSS version 24. The results were compiled based on the scale of Always, Sometimes and Never from the male and female students of different nationalities, mediums of instruction, colleges and years of study.

The questionnaire was divided into 8 sections. Each section had a set of questions according to:

1. Demographic details

2. Time management

3. Study environment

4. Methods of study

5. Preparation of exams

6. Device used for studying

7. Hours/day spent on technology

8. Role of technology in improving the learning experience

\section{Results}

Table1: Demographic details of study participants

\begin{tabular}{|l|l|l|l|}
\hline \multicolumn{2}{|l|}{ Items } & Na306 & \% \\
\hline Gender & Male & 98 & 32 \\
\cline { 2 - 4 } & Female & 208 & 68 \\
\hline \multirow{4}{*}{ Nationality } & Arab & 212 & 69.3 \\
\cline { 2 - 4 } & Non-Arab & 94 & 30.7 \\
\hline \multirow{4}{*}{$\begin{array}{l}\text { Medium of Instructioge } \\
\text { (High School) }\end{array}$} & Medical & 113 & 36.9 \\
\hline \multirow{4}{*}{ Year of Study } & Nursing & 58 & 19 \\
\cline { 2 - 4 } & Dental & 91 & 29.7 \\
\cline { 2 - 4 } & Pharmacy & 44 & 14.4 \\
\cline { 2 - 4 } & Arabic & 132 & 43.1 \\
\hline & English & 174 & 56.9 \\
\cline { 2 - 4 } & First & 53 & 17.3 \\
\cline { 2 - 4 } & Second & 72 & 23.5 \\
\cline { 2 - 4 } & Third & 47 & 15.4 \\
\cline { 2 - 4 } & Fourth & 97 & 31.7 \\
\cline { 2 - 4 } & Fifth & 37 & 12.1 \\
\hline
\end{tabular}

Table 1 shows that the total number of respondents was 306, out of which there were $208(68 \%)$ females and 98 (32\%) males. 212 participants $(69.3 \%)$ of the study population were Arabs as compared to $94(30.7 \%)$ of Non- Arabs. Maximum number of participants i.e. 113 (36.9\%) were studying in College of Medicine, $91(29.7 \%)$ in Dental College, as compared to $44(14.4 \%)$ of Pharmacy College, and 58 (19\%) in the Nursing College. Majority of students, i.e. 174 (56.9\%) studied in English Medium schools and maximum number of respondents i.e. 97 (31.7\%) were from the 4 th year of study.

Table 2: Relation between selected variables and Time Management $(\mathrm{N}=306)$

\begin{tabular}{|c|c|c|c|c|c|c|c|c|c|c|c|c|c|c|c|c|c|c|c|c|c|c|}
\hline \multirow{3}{*}{$\begin{array}{l}\text { Items } \\
\text { I prefer to : }\end{array}$} & \multicolumn{6}{|c|}{ Medium of Study(High school) } & \multirow{3}{*}{$\begin{array}{c}\text { Chi } \\
\text { Squa } \\
\text { re } \\
\end{array}$} & \multirow{3}{*}{$\begin{array}{l}\text { p- } \\
\text { val } \\
\text { ue } \\
\end{array}$} & \multicolumn{12}{|c|}{ College } & \multirow{3}{*}{$\begin{array}{l}\text { Chi- } \\
\text { Squar } \\
\text { e } \\
\end{array}$} & \multirow{3}{*}{$\begin{array}{c}\mathrm{p}- \\
\text { value }\end{array}$} \\
\hline & \multicolumn{3}{|c|}{ Arabic } & \multicolumn{3}{|c|}{ English } & & & \multicolumn{3}{|c|}{ Medical } & \multicolumn{3}{|c|}{ Nursing } & \multicolumn{3}{|c|}{ Dental } & \multicolumn{3}{|c|}{ Pharmacy } & & \\
\hline & $\mathrm{N}$ & $\mathrm{S}$ & $\mathrm{A}$ & $\mathrm{N}$ & $\mathrm{S}$ & A & & & $\mathrm{N}$ & $\mathrm{S}$ & $\mathrm{A}$ & $\mathrm{N}$ & $\mathrm{S}$ & $\mathrm{A}$ & $\mathrm{N}$ & $\mathrm{S}$ & A & $\mathrm{N}$ & $\mathrm{S}$ & A & & \\
\hline $\begin{array}{l}\text { prepare a } \\
\text { study } \\
\text { schedule in } \\
\text { the } \\
\text { beginning } \\
\text { of semester }\end{array}$ & 29 & 71 & 30 & 54 & 85 & 32 & 3.32 & $\begin{array}{l}0.1 \\
89\end{array}$ & 37 & 48 & 23 & 7 & 34 & 17 & 27 & $\begin{array}{l}5 \\
1\end{array}$ & 13 & 12 & 23 & 9 & 12.84 & 0.46 \\
\hline stick to the & 38 & 58 & 34 & 53 & 81 & 37 & 0.83 & 0.6 & 43 & 46 & 19 & 8 & 22 & 28 & 30 & 4 & 16 & 10 & 26 & 8 & 31.03 & 0.000 \\
\hline
\end{tabular}




\begin{tabular}{|l|l|l|l|l|l|l|l|l|l|l|l|l|l|l|l|l|l|l|l|l|l|l|}
\hline $\begin{array}{l}\text { prepared } \\
\text { schedule }\end{array}$ & & & & & & & & 58 & & & & & & & & 5 & & & & & \\
\hline $\begin{array}{l}\text { study at } \\
\text { night }\end{array}$ & 17 & 54 & 59 & 12 & 56 & 10 & 7.40 & 0.0 & 17 & 40 & 51 & 3 & 20 & 35 & 5 & 3 & 50 & 4 & 14 & 26 & 9.16 & 0.165 \\
\hline $\begin{array}{l}\text { study early } \\
\text { in the } \\
\text { morning }\end{array}$ & 19 & 71 & 40 & 38 & 85 & 48 & 2.78 & $\begin{array}{l}2.2 \\
49\end{array}$ & 25 & 45 & 38 & 2 & 25 & 13 & 7 & 6 & 23 & 5 & 25 & 14 & 25.91 & 0.000 \\
\hline $\begin{array}{l}\text { meet the } \\
\text { deadlines } \\
\text { of my } \\
\text { assigned } \\
\begin{array}{l}\text { work on } \\
\text { time }\end{array}\end{array}$ & 10 & 40 & 80 & 3 & 36 & 13 & 11.36 & 0.0 & 4 & 19 & 85 & 1 & 24 & 33 & 5 & 2 & 64 & 3 & 11 & 30 & 13.04 & 0.042 \\
\hline $\begin{array}{l}\text { attend my } \\
\text { lecture } \\
\text { classes } \\
\text { regularly }\end{array}$ & 14 & 23 & 93 & 7 & 42 & 12 & 7.09 & 0.0 & 9 & 24 & 74 & 8 & 5 & 45 & 4 & 2 & 60 & 0 & 9 & 35 & 18.41 & 0.031 \\
\hline $\begin{array}{l}\text { attend } \\
\text { rotation/fiel } \\
\text { d visits } \\
\text { regularly }\end{array}$ & 20 & 56 & 51 & 3 & 23 & 40 & 100 & 0.0 & 14 & 25 & 68 & 1 & 20 & 27 & 14 & 3 & 35 & 4 & 15 & 21 & 22.62 & 0.007 \\
\hline $\begin{array}{l}\text { utilize the } \\
\text { free time } \\
\text { between } \\
\text { classes to } \\
\text { study }\end{array}$ & 33 & 74 & 23 & 45 & 90 & 35 & 1.33 & 0.7 & 27 & 51 & 30 & 5 & 45 & 8 & 36 & 4 & 14 & 10 & 28 & 6 & 31.40 & 0.000 \\
\hline
\end{tabular}

$N=$ Never $S=$ Sometimes $A=$ Always

Table 2 depicts that $156(51.8 \%)$ of the study population sometimes prepared a study schedule at the beginning of the semester and only $139(45 \%)$ of them followed the prepared schedule throughout the semester. Approximately half of the study population i.e.162 (52.9\%) preferred to study at night as compared to 88 students $(28.8 \%)$ who preferred to study in the morning. It was noted that $214(71 \%)$ students attended lectures regularly but a slight drop was seen in the field visits/ rotations where only 151 (49.3\%) students regularly attended the field rotations and $164(53.6 \%)$ students sometimes utilized their free time in between classes to study.

Interestingly, 17 (29.3\%) students from Nursing College always prepared a schedule at the beginning of the semester as compared to $23(21.3 \%)$ from Medical College 9 (20.5\%) from Pharmacy College and only 13 (14.4\%) from Dental College which was statistically significant with a $\mathrm{p}$-value of $\mathrm{p}=0.046$.

In comparison with the different colleges at RAK Medical and Health Sciences University less than half 28 (48.3\%) of the students from Nursing College always preferred to stick to the schedule as compared to only 19 (17.6\%) from Medical College, 16 (17.6\%) from Dental College and 8 (18.2\%) from Pharmacy College which is statistically significant, $\mathrm{p}=0.000$.

It is interesting to note that $103(60.2 \%)$ students from English medium school preferred to study at night compared to 59 (45.4\%) of the Arabic medium. This shows statistical significance with $\mathrm{p}=0.08$.

Table 3: Relation between selected variables (medium of school study and college) and study environment of the participants ( $\mathrm{N}=306$ )

\begin{tabular}{|c|c|c|c|c|c|c|c|c|c|c|c|c|c|c|c|c|c|c|c|c|c|c|}
\hline \multirow{3}{*}{$\begin{array}{l}\text { Items } \\
\text { I prefer to: }\end{array}$} & \multicolumn{6}{|c|}{ Medium of Study(High school) } & \multirow{3}{*}{$\begin{array}{c}\text { Chi } \\
\text { Square }\end{array}$} & \multirow{3}{*}{$\begin{array}{c}\mathrm{p}- \\
\text { value }\end{array}$} & \multicolumn{12}{|c|}{ College } & \multirow{3}{*}{$\begin{array}{l}\text { Chi- } \\
\text { Square }\end{array}$} & \multirow{3}{*}{$\begin{array}{c}\mathrm{p}- \\
\text { value }\end{array}$} \\
\hline & \multicolumn{3}{|c|}{ Arabic } & \multicolumn{3}{|c|}{ English } & & & \multicolumn{3}{|c|}{ Medical } & \multicolumn{3}{|c|}{ Nursing } & \multicolumn{3}{|c|}{ Dental } & \multicolumn{3}{|c|}{ Pharmacy } & & \\
\hline & $\mathrm{N}$ & $\mathrm{S}$ & A & $\mathrm{N}$ & $\mathrm{S}$ & A & & & $\mathrm{N}$ & $\mathrm{S}$ & A & $\mathrm{N}$ & $\mathrm{S}$ & $\mathrm{A}$ & $\mathrm{N}$ & $\mathrm{S}$ & $\mathrm{A}$ & $\mathrm{N}$ & $\mathrm{S}$ & $\mathrm{A}$ & & \\
\hline $\begin{array}{l}\text { listen to } \\
\text { the lectures } \\
\text { attentively }\end{array}$ & 4 & $\begin{array}{l}7 \\
1\end{array}$ & 55 & 0 & $\begin{array}{l}9 \\
0\end{array}$ & 81 & 5.735 & 0.057 & 0 & 58 & 50 & 0 & 37 & 21 & 4 & 46 & 41 & 0 & 20 & 24 & 12.979 & 0.043 \\
\hline $\begin{array}{l}\text { have a } \\
\text { designated } \\
\text { area that is } \\
\text { free of } \\
\text { noise and } \\
\text { distraction }\end{array}$ & $\begin{array}{l}1 \\
7\end{array}$ & $\begin{array}{l}5 \\
5\end{array}$ & 58 & 12 & $\begin{array}{l}5 \\
9\end{array}$ & $\begin{array}{c}10 \\
0\end{array}$ & 6.707 & 0.035 & 11 & 42 & 55 & 12 & 14 & 32 & 3 & 43 & 45 & 3 & 15 & 26 & 17.401 & 0.008 \\
\hline $\begin{array}{l}\text { study in } \\
\text { the library }\end{array}$ & $\begin{array}{l}2 \\
9\end{array}$ & $\begin{array}{l}7 \\
5\end{array}$ & 26 & 34 & $\begin{array}{l}9 \\
8\end{array}$ & 39 & 0.479 & 0.787 & 19 & 58 & 31 & 7 & 35 & 16 & 30 & 51 & 10 & 7 & 29 & 8 & 18.976 & 0.004 \\
\hline $\begin{array}{l}\text { coffee } \\
\text { shops }\end{array}$ & $\begin{array}{l}9 \\
1\end{array}$ & $\begin{array}{l}2 \\
4\end{array}$ & 15 & $\begin{array}{c}13 \\
9\end{array}$ & $\begin{array}{l}1 \\
3\end{array}$ & 19 & 8.328 & 0.016 & 99 & 4 & 5 & 30 & 13 & 15 & 71 & 9 & 11 & 30 & 11 & 3 & 41.833 & 0 \\
\hline
\end{tabular}

$N=$ Never $S=$ sometimes $A=A l$ ways studied early in the morning compared to $25(23.1 \%)$ who never studied early in the morning. $61(67 \%)$ students from Dental College sometimes preferred to study early in the morning.

More than half of the respondents, i.e., 156 (51.8\%) sometimes studied in the morning out of which $61(67 \%)$ were from Dental College followed by 25 (56.8\%), 25 (43.1\%) and 45 (41.7\%) from Pharmacy College, Nursing College \& Medical College respectively. About 212, i.e., majority of students (70.4\%) always met the deadlines of assigned work. Out of these, 85 $(78.7 \%)$ were students of Medical College, 64 (70.3\%), and 30 (68.2\%) from Dental College and Pharmacy College respectively. The lowest was noted in Nursing College with 33 (56.9\%) students amongst whom132 (77.2\%) were from English medium school compared to $80(61.5 \%)$ from Arabic medium with a p-value of 0.003 showing a statistical significance.

A total of $214(71.1 \%)$ students always attended lectures regularly out of which 35 (79.5\%) were from Pharmacy College 45 $(77.6 \%)$ from Nursing College, $74(68.5 \%)$ and 60 (65.9\%) from Medical College and Dental College respectively which shows a statistical significance $(\mathrm{p}=0.031)$

Field rotations were mostly attended by 100 (58.5\%) students who studied in an English medium school as compared to $51(39.2 \%)$ students from Arabic medium.

623
623




\section{Study Environment}

The data shows that only $136(44.4 \%)$ students attentively listened to the lectures out of which, $24(54.5 \%)$ students were from Pharmacy College as compared to $21(36.2 \%)$ from Nursing College with a p-value of 0.043 showing statistical significance.

Out of the 306 respondents, $26(59.1 \%)$ students from Pharmacy College followed by 32 (55.2\%), 55 (50.9\%) and 45 $(49.5 \%)$ from Nursing College, Medical College and Dental College respectively, preferred to study in a designated area free of noise which shows statistical significance as the $p<0.05 .100$
(58.5\%) students were from English medium school as compared to $58(44.6 \%)$ students from Arabic medium. This shows statistical significance with a p-value of 0.035 .

Out of $306,174(56.9 \%)$ students preferred to study alone and they studied in the library as compared to $176(57.5 \%)$ students who preferred to study in groups. Only $31(28.7 \%)$ students from medical college as compared to $10(11 \%)$ students from dental college, always utilized the Library to study. The p-value of 0.004 shows statistical significance as.

A majority of the students i.e., 230 (76.4\%) never utilized other places to study other than their home or library.

Table 4: Relation between selected variables and methods of studying $(\mathrm{N}=306)$

\begin{tabular}{|c|c|c|c|c|c|c|c|c|c|c|c|c|c|c|c|c|c|c|c|c|c|c|}
\hline \multirow{3}{*}{$\begin{array}{l}\text { Items } \\
\text { I prefer } \\
\text { to : }\end{array}$} & \multicolumn{6}{|c|}{ Medium of Study(High school) } & \multirow{3}{*}{$\begin{array}{c}\text { Chi } \\
\text { Square }\end{array}$} & \multirow{3}{*}{$\begin{array}{c}\mathrm{p}- \\
\text { value }\end{array}$} & \multicolumn{12}{|c|}{ College } & \multirow{3}{*}{$\begin{array}{c}\text { Chi- } \\
\text { Square }\end{array}$} & \multirow{3}{*}{$\begin{array}{c}\mathrm{p}- \\
\text { value }\end{array}$} \\
\hline & \multicolumn{3}{|c|}{ Arabic } & \multicolumn{3}{|c|}{ English } & & & \multicolumn{3}{|c|}{ Medical } & \multicolumn{3}{|c|}{ Nursing } & \multicolumn{3}{|c|}{ Dental } & \multicolumn{3}{|c|}{ Pharmacy } & & \\
\hline & $\mathrm{N}$ & $\mathrm{S}$ & A & $\mathrm{N}$ & $\mathrm{S}$ & A & & & $\mathrm{N}$ & $\mathrm{S}$ & A & $\mathrm{N}$ & $\mathrm{S}$ & A & $\mathrm{N}$ & S & A & $\mathrm{N}$ & $\mathrm{S}$ & A & & \\
\hline $\begin{array}{l}\text { my } \\
\text { persona } \\
1 \text { copy } \\
\text { of } \\
\text { textboo } \\
\mathrm{k}\end{array}$ & $\begin{array}{l}3 \\
4\end{array}$ & 50 & 46 & 22 & 64 & 85 & 10.512 & 0.005 & 12 & 30 & 66 & 5 & 33 & 20 & 26 & 34 & 31 & 13 & 17 & 14 & 34.539 & 0 \\
\hline $\begin{array}{l}\text { Library } \\
\text { copy }\end{array}$ & $\begin{array}{l}3 \\
2\end{array}$ & 71 & 27 & 29 & $\begin{array}{c}10 \\
1\end{array}$ & 41 & 2.728 & 0.256 & 21 & 57 & 30 & 5 & 44 & 9 & 29 & 42 & 20 & 6 & 29 & 9 & 20.022 & 0.003 \\
\hline e-book & $\begin{array}{l}3 \\
5 \\
\end{array}$ & 49 & 42 & 48 & 68 & 44 & 2.904 & 0.407 & 35 & 36 & 37 & 15 & 27 & 16 & 19 & 30 & 27 & 14 & 24 & 6 & 47.404 & 0 \\
\hline $\begin{array}{l}\text { Lecture } \\
\text { s/Ppt. }\end{array}$ & 4 & 18 & $\begin{array}{c}10 \\
1\end{array}$ & 1 & 26 & $\begin{array}{c}13 \\
4\end{array}$ & 2.887 & 0.409 & 0 & 22 & 85 & 0 & 14 & 43 & 5 & 2 & 70 & 0 & 6 & 37 & 49.559 & 0 \\
\hline Journals & $\begin{array}{l}4 \\
3\end{array}$ & 62 & 18 & 69 & 60 & 28 & 5.085 & 0.166 & 46 & 43 & 16 & 16 & 27 & 14 & 30 & 37 & 12 & 20 & 15 & 4 & 20.135 & 0.17 \\
\hline $\begin{array}{l}\text { Teacher } \\
\mathrm{s} \text { notes }\end{array}$ & 7 & 33 & 90 & 6 & 47 & $\begin{array}{c}11 \\
6\end{array}$ & 2.266 & 0.519 & 7 & 20 & 81 & 2 & 24 & 32 & 4 & 26 & 59 & 0 & 10 & 34 & 18.435 & 0.03 \\
\hline $\begin{array}{l}\text { Revisio } \\
\mathrm{n} \\
\text { classes }\end{array}$ & $\begin{array}{l}1 \\
0\end{array}$ & 53 & 67 & 10 & 51 & $\begin{array}{c}11 \\
0\end{array}$ & 4.993 & 0.082 & 8 & 29 & 71 & 6 & 31 & 21 & 4 & 29 & 58 & 2 & 15 & 27 & 16.66 & 0.011 \\
\hline
\end{tabular}

$N=$ Never $S=$ Sometimes $A=$ Always

\section{Methods of Studying}

In this study only $131(42.8 \%)$ of students used their personal textbook for studying, out of which $85(48.8 \%)$ were from English medium school who always had personal textbook copies and 46 (34.8\%) students were from Arabic medium school showing a statistical significance $(\mathrm{p}=0.005) .66(61.11 \%)$ of students from Medical College had a personal copy of textbook as compared to 20 (35\%) from Nursing College, 31 (34.1\%) from Dental College and $14(31.8 \%)$ from Pharmacy College, with a p-value of 0.000 .

Out of the total 306 students, $172(57.1 \%)$ of students sometimes preferred to use library copy of textbooks of which 44 (75.9\%) were from Nursing College. 29 (65.9\%) from Pharmacy College, 57 (52.8\%) from Medical College and 42 (46.2\%) from Dental College $(\mathrm{p}=0.000)$

It was noted that $235(78.1 \%)$ of students were dependent on and studied from the lecture, $47.7 \%$ and $39.9 \%$ only used online resources and journals respectively. However most of the students were dependent on teacher's notes.
Surprisingly only $46(15.3 \%)$ students preferred to use journals of which 16 (14.8\%) students were from Medical College, $14(24.1 \%)$ from Nursing College, 12 (13.2\%) from Dental College and $4(11.4 \%)$ from Pharmacy College. However, it is interesting to note that amongst the $112(37.2 \%)$ students who never used a journal, the highest percentage was seen in Pharmacy College with $20(45.5 \%)$ followed by $46(42.6 \%)$ from Medical College $\mathrm{p}=0.17$.

$34(77.3 \%)$ students from Pharmacy College as compared to $32(55.2 \%)$ from Nursing College preferred teachers notes. This is directly proportional to the finding where $84.1 \%$ of students from Pharmacy College always preferred to use lectures/ PowerPoint to study.

$71(65.7 \%)$ students from Medical College, always preferred revision classes as opposed to $21(36.2 \%)$ students from Nursing College $\mathrm{P}=0.11(\mathrm{p}$-value $<0.05)$.

Learning methods that helped the students to understand the subject better

There was no major statistical significance noted in relation between gender, nationality, medium of school and college.

Table 5: Relation between selected variables and preparation for exams $(\mathrm{N}=306)$

\begin{tabular}{|c|c|c|c|c|c|c|c|c|c|c|c|c|c|c|c|c|c|c|c|c|c|c|}
\hline \multirow{3}{*}{$\begin{array}{l}\text { Items } \\
\text { I prefer } \\
\text { to : }\end{array}$} & \multicolumn{6}{|c|}{ Medium of Study(High school) } & \multirow{3}{*}{$\begin{array}{l}\text { Chi } \\
\text { Squa } \\
\text { re }\end{array}$} & \multirow{3}{*}{$\begin{array}{l}\text { p- } \\
\text { val } \\
\text { ue }\end{array}$} & \multicolumn{12}{|c|}{ College } & \multirow{3}{*}{$\begin{array}{l}\text { Chi- } \\
\text { Squa } \\
\text { re }\end{array}$} & \multirow{3}{*}{$\begin{array}{l}\text { p- } \\
\text { val } \\
\text { ue }\end{array}$} \\
\hline & \multicolumn{3}{|c|}{ Arabic } & \multicolumn{3}{|c|}{ English } & & & \multicolumn{3}{|c|}{ Medical } & \multicolumn{3}{|c|}{ Nursing } & \multicolumn{3}{|c|}{ Dental } & \multicolumn{3}{|c|}{ Pharmacy } & & \\
\hline & $\mathrm{N}$ & $\mathrm{S}$ & A & $\mathrm{N}$ & $\mathrm{S}$ & $\mathrm{A}$ & & & $\mathrm{N}$ & $\mathrm{S}$ & $\mathrm{A}$ & $\mathrm{N}$ & $\mathrm{S}$ & $\mathrm{A}$ & $\mathrm{N}$ & $\mathrm{S}$ & A & $\mathrm{N}$ & $\mathrm{S}$ & A & & \\
\hline $\begin{array}{l}\text { start my } \\
\text { preparati } \\
\text { on much } \\
\text { in }\end{array}$ & 17 & 66 & 47 & 21 & 93 & 57 & \begin{tabular}{|c|}
0.39 \\
\end{tabular} & $\begin{array}{l}0.8 \\
23\end{array}$ & 14 & 56 & 38 & 2 & 38 & 18 & 16 & 50 & 25 & 6 & 15 & 23 & $\begin{array}{l}16.01 \\
4\end{array}$ & $\begin{array}{l}0.01 \\
4\end{array}$ \\
\hline
\end{tabular}




\begin{tabular}{|c|c|c|c|c|c|c|c|c|c|c|c|c|c|c|c|c|c|c|c|c|c|c|}
\hline advance & & & & & & & & & & & & & & & & & & & & & & \\
\hline $\begin{array}{l}\text { start my } \\
\text { preparati } \\
\text { on a day } \\
\text { before } \\
\text { the } \\
\text { exam }\end{array}$ & 32 & 40 & 58 & 55 & 68 & 48 & 8.863 & $\begin{array}{l}0.0 \\
12\end{array}$ & 40 & 44 & 24 & 12 & 14 & 32 & 25 & 32 & 34 & 10 & 18 & 16 & $\begin{array}{l}19.60 \\
7\end{array}$ & $\begin{array}{l}0.00 \\
3\end{array}$ \\
\hline $\begin{array}{l}\text { study } \\
\text { only } \\
\text { selected } \\
\text { importa } \\
\text { nt topics } \\
\text { for the } \\
\text { exam }\end{array}$ & 29 & 59 & 42 & 49 & 76 & 46 & 1.901 & $\begin{array}{l}0.3 \\
86\end{array}$ & 27 & 57 & 24 & 9 & 25 & 24 & 25 & 34 & 32 & 17 & 19 & 8 & $\begin{array}{l}15.68 \\
1\end{array}$ & $\begin{array}{l}0.01 \\
6\end{array}$ \\
\hline $\begin{array}{l}\text { study all } \\
\text { the } \\
\text { topics } \\
\text { included } \\
\text { for the } \\
\text { exam }\end{array}$ & 12 & 28 & 90 & 12 & 51 & 108 & 2.8 & $\begin{array}{l}0.2 \\
47\end{array}$ & 9 & 36 & 63 & 9 & 17 & 32 & 2 & 25 & 64 & 4 & 1 & 39 & $\begin{array}{l}25.67 \\
8\end{array}$ & 0 \\
\hline
\end{tabular}

$N=$ Never $S=$ Sometimes $A=$ Always

Out of the total 306 participants, only 104 (34.6\%) of students always prepared for the exam much in advance but 159 (52.8\%) sometimes started preparation for the exam much in advance. Of all the colleges $23(52.3 \%)$ of students from Pharmacy College always prepared much in advance as compared to $25(27.5 \%)$ from Dental College, $p=0.14$. It was noted that 32 i.e. more than $50 \%$ of students from Nursing College started preparation a day before the exam as compared to $24(22.2 \%)$ of students from Medical College $=0.003$.

$57(52.8 \%)$ of students from Medical College sometimes studied only selected important topics for the exam as compared to $25(41.4 \%)$ of students from Nursing College who always studied selected topics for the exam $\mathrm{p}=0.016$.

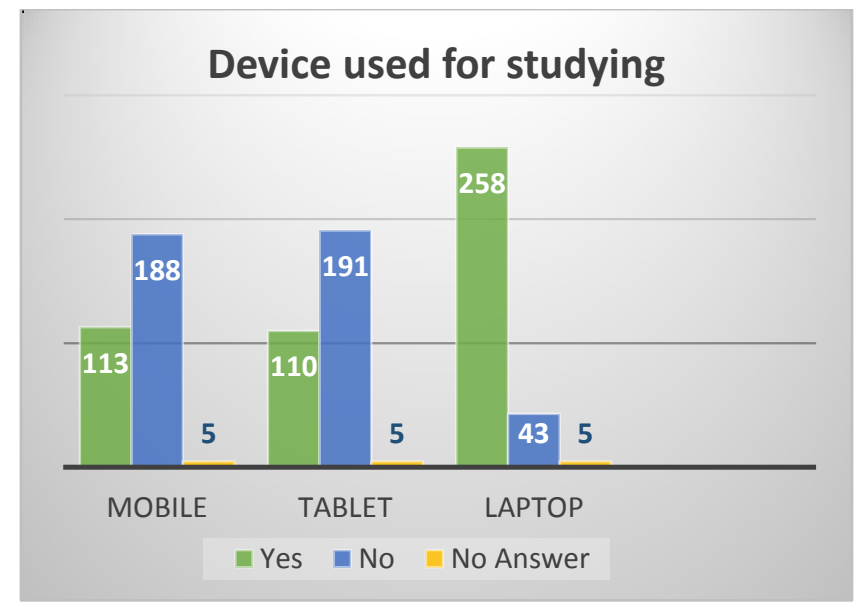

\section{Device used for studying}

A majority of 258 (84.3\%) students utilized laptop for studying as compared to mobile and tablet. It was surprising to note that most of the students did not prefer to use their mobile for studying and it was not statistically significant. It was noted that $262(85.7 \%)$ students preferred to utilize the laptop for studying for the exam. College wise it was noted that $(90.1 \%)$ from Medical College, $89.8 \%$ from Dental College and $86.2 \%$ Nursing College preferred to study from the laptop for the exam. Only $65.9 \%$ students from Pharmacy College preferred laptop probably because they preferred to study from lecture notes as noted previously. $48.3 \%$, $38.9 \%, 34.1 \%$ and $20.5 \%$ students from Nursing College, Medical College, Dental College and Pharmacy College respectively preferred to use the tablet for studying for the exam. The results were statistically significant with $\mathrm{p}=0.31$.

Number of hours / days spent on technology hours

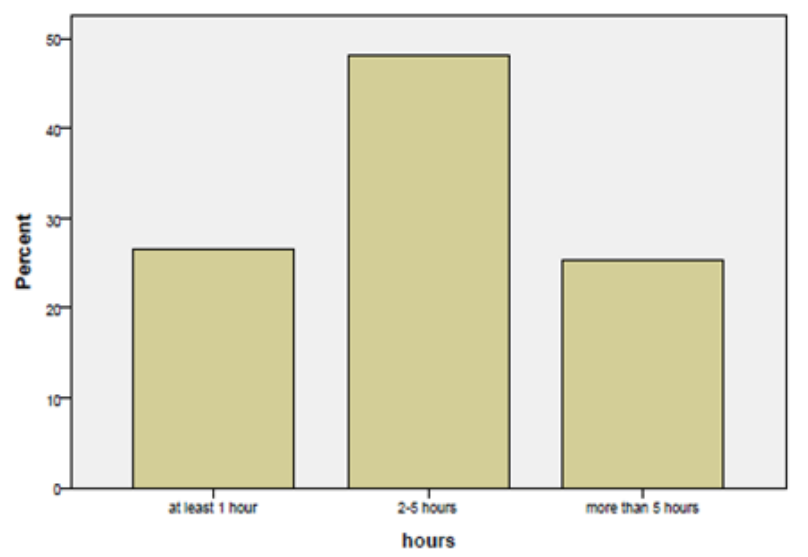

Figure 2: Number of hours spent on technology to facilitate learning

As shown in the graph, about 77 (25\%) students spend more than 5 hours in a day, 145 (47.4\%) students spend 2-5 hours on technology every day and only a meagre 80 (26\%) students use technology for less than an hour.

\section{Role of technology in improving learning experience}

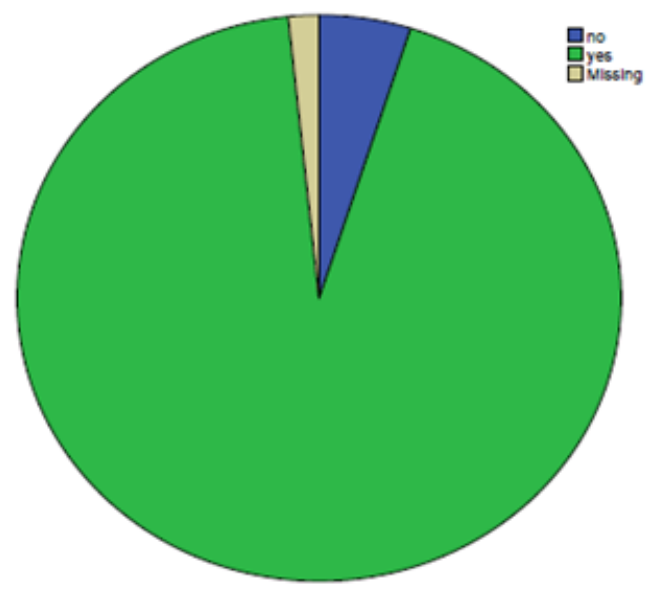

Figure 3: Does technology improve your learning experience 
A whopping number of 291 (95\%) students in the study expressed that technology improved their learning experience.

\section{Discussion}

This research has proved that study habits of students and technology are strongly related. Michael, (2001) supports the idea that it is important to use technology and it should be incorporated in the daily activities of clinical and basic sciences. Morgan Noble (2015) is of the opinion that the focus of students in the classroom may have decreased slightly, but the amount of information at their fingertips has also helped their learning. It has provided access to some study tools they otherwise would not have had. It was noted that more than $50 \%$ of the students prepared a schedule and most of them tried to follow it. More than half of the study population preferred to study at night. A noticeable range of $70.4 \%$ students met the deadlines of the assigned work which is a very encouraging attitude. It is interesting to see that this statistics matches with the study conducted by Michael, (2014) where it was stated that $68.31 \%$ respondents always met the deadlines of the assigned work. As far as studying in groups and studying alone is concerned, an approximately equal number of students preferred to study in groups $(57.5 \%)$ and alone $(56.9 \%)$ which opposes the study conducted by Andrea, et. al., (2015) where more than $54.1 \%$ students preferred to study alone but a slightly lesser percentage (50.4\%) studied in groups. Moreover, this research found that only $42.8 \%$ of the students used their personal textbooks in the university while $78.1 \%$ used the lectures/power points. This is also opposed to a study by Andrea, et. al., (2015) done in an Italian university where majority of the students used their text-books. Similar to a research conducted by Mohammed, (2017) where almost $86 \%$ participants utilized the laptop for studying, $85.7 \%$ students of this university preferred to use their laptops instead of mobiles.

\section{Conclusion}

The study investigated the study habits of students studying in a medical and health sciences university in the UAE, and concluded that technology has played an important role in influencing the study habits of students. Students rely on technology for their studies instead of text books. Further studies can be conducted to investigate how technology can be used to improve their psychomotor and linguistic skills including communication skills which are vital for health care professionals

\section{Conflict of interest}

None

\section{Funding Statement}

Not funded

\section{Acknowledgments}

The authors would like to thank the president, Dr. Gurumadhva Rao, RAKMHSU Research and Ethical Committee, Deans of all Colleges, Chairpersons, Faculty, staff and students of RAKMHSU for their support in conducting the survey.

\section{References}

[1] Al Hilawani, Y.A and Sartawi AA. Study skills and habits of female university students. Coll Stud J 1997;31:537-44.

[2] Andrea, P. et. al., Study habits and technology use in Italian university students, 51(2), p.127-128 (2015).

[3] Berner, E. \& Boulware, D (1996). Medical informatics for medical students: not just because it's there. Medical Education Online, 1 Google Scholar

[4] Colley, A. and Maltby, J. (2008). Impact of the Internet on our lives: Male and female personal perspectives. Computers in Human Behavior, 24, 2005-13

[5] Cradler, J. et al. (2002) How does technology influence student learning? Learning and Leading with Technology, v29 n8 p46-49,56

[6] International ICT Literacy Panel (IILP). (2002). Digital transformation: A framework for ICT literacy. Princeton: Educational Testing Service (ETS). ICT literacy. http://www.ets.org/media/Tests/Information and_communication_Technology_literacy/ ictreport.pdf. Google Scholar.

[7] Marc, J. Rosenberg, (2001) E learning: Strategies for delivering knowledge in the digital age, vol.3, McGrawHill, New York.

[8] Mayer, R. (2014). The Cambridge Handbook of Multimedia Learning. In R. Mayer (Ed.), The Cambridge Handbook of Multimedia Learning (Cambridge Handbooks in Psychology, p. Iii). Cambridge: Cambridge University Press.

[9] Michael, J.,(2001). In pursuit of meaningful learning, Advances in Physiology Education, 27 (3) pp. 145-158 https://doi.org/10.1152/advances.2001.25.3.145

[10] Michael, J., \& Samuel, O. et. al., (2014) Study habits of school libraries and students' academic performance in selected secondary schools in Ondo West Local Government Area of Ondo State, International Journal of Library and Information Science 6(4) p. 61

[11] Mohammed, T., \& Abdulghani, A. (2017). Impact of students' use of technology on their learning achievements in physiology courses at the University of Dammam, Journal of Taibah University of Medical Sciences, 12 (1), p.84

[12] Noble, M. (2015) Technology impacts students' study habits. Daily Toreador.com. Retrieved from http://www.dailytoreador.com/lavida/technologyimpacts-students-study-habits/article_8bbeb9d0-a5d611e4-b814-d3a846b0ebd4.html on 21st October, 2019

[13] Stella E. Igun, Oghenevwogaga Benson Adogbeji. (2007) Study Habits of Postgraduate Students in Selected Nigerian Universities, Library Philosophy and Practice (e-journal) http://digitalcommons.unl.edu/libphilprac/153

[14] Yamani, H. (2006) Electronic learning to face challenges of Saudi higher education in the light of requests of technology age. Unpublished master's thesis, Umm AlQura University, Saudi Arabia (2006) Google Scholar 